\title{
PANORAMA PEMBELAJARAN PENDIDIKAN \\ AGAMA ISLAM PADA ANAK \\ BERKEBUTUHAN KHUSUS \\ (Studi Kasus : Sekolah Luar Biasa ABCD \\ Dharmawanita Herlang)
}

\author{
Khairun Nisa'*
}

Balai Peneitian dan Pengembangan Agama Makassar JI. AP.Pettarani No.72 Makassar Email: kn.khaerunnisa@gmail.com

INFO ARTIKEL

Kata Kunci:

Pembelajaran

Pendidikan Agama

Islam, Anak

Berkebutuhan

Khusus, Sekolah

Luar Biasa

Keywords:

Islamic Religion

Education Learning,

Children with

\section{ABSTRAK}

Setiap anak memiliki kesempatan yang sama untuk memperoleh pendidikan, dalam hal ini Pendidikan Agama Islam untuk anak berkebutuhan khusus. Penelitian ini bertujuan untuk melihat panorama pembelajaran PAI pada anak berkebutuhan khusus pada SLB ABCD Dharmawanita Herlang, yang meliputi perencanaan, pelaksanaan dan evaluasi pembelajaran PAI. Dengan menggunakan metode kualitatif, diperoleh bahwa Kurikulum PAI yang digunakan pada SLB ABCD Dharmawanita Herlang mengikuti kurikulum pada sekolah umum, yaitu kurikulum 2013. Metode yang dominan digunakan dalam proses pembelajaran PAI, yaitu metode yang masih bersifat teacher learning centre, seperti metode ceramah dan metode demontrasi. Pembelajaran bersifat individual teaching. Sistem evaluasi tetap menggunakan tiga ranah; kognitif, afektif dan psikomotorik, meskipun komponen kognitif tidak menjadi acuan utama, namun lebih kepada kemampuan peserta didik mengimplementasikan materi pembelajaran PAI dalam kehidupan sehari-hari. Adapun kendala dalam penyelenggaraan pembelajaran PAI pada SLB ABCD Dharmawanita Herlang adalah pertama kurangnya guru PAI yang memiliki spesifikasi khusus dalam pendidikan luar biasa, kedua belum tersedianya kurikulum PAI yang dirancang khusus untuk anak berkebutuhan khusus, karena selama ini kurikulum PAI yang digunakan umumnya berasal dari sekolah umum yang sedikit mengalami modifikasi dan adaptasi untuk anak berkebutuhan khusus. Ketiga, minimnya ketersediaan buku-buku PAI bagi peserta didik berkebutuhan khusus yang disediakan oleh pihak SLB, khususnya bagi peserta didik tunanetra yang membutuhkan buku braille. Keempat, perlunya guru melakukan pendekatan secara emosional sebab peserta didik yang berkebutuhan khusus memiliki kecenderungan akan lebih nyaman dan lebih mudah berkompromi terhadap instruksi yang disampaikan oleh guru, apabila telah memiliki kedekatan emosial.

ABSTRACT

Every child has the same opportunity to obtain education, including in this case Islamic Religious Education for children with special needs. This study aims to see the panoramic view of PAI learning for children with special needs in SLB $A B C D$ Dharmawanita Herlang, which includes the planning, implementation and evaluation of PAI learning. By using qualitative methods, it was found that the PAI curriculum used in SLB ABCD Dharmawanita Herlang followed the curriculum in public schools, namely the 2013 curriculum. The dominant method used in the PAI learning process was the method of teacher learning center, such as lecture and demonstration methods. The learning is individual teaching. The evaluation system still uses three domains; cognitive, affective and psychomotor, although the cognitive component is not the main focus, but more on the ability of students to implement PAI learning material in daily activities. The obstacles in organizing PAI learning in SLB ABCD Dharmawanita Herlang are firstly the lack of PAI teachers who have special specifications in special education, secondly there is no available PAI curriculum specifically designed for children with special needs, because the PAI curriculum used so far generally comes from public schools, which is slightly modified and adapted for children with special needs. Third, the lack of availability of PAI books for students with special needs provided by the SLB, especially for blind students who need braille books. 


\begin{tabular}{lll}
$\begin{array}{l}\text { Special Needs, } \\
\text { Special School }\end{array}$ & $\begin{array}{l}\text { Fourth, teachers need to use an emotional approach because students with } \\
\text { special needs have a tendency to be more comfortable and easier to compromise } \\
\text { on instructions delivered by the teacher if they have emotional attachment. }\end{array}$ \\
\hline
\end{tabular}

\section{PENDAHULUAN}

Stereotip sebagian masyarakat Indonesia terhadap anak berkebutuhan khusus hingga saat ini tidak dapat ditepis. Mulai dari anggapan bahwa anak berkebutuhan khusus merupakan sebuah hukuman atas perbuatan yang dilakukan oleh orang tua dari anak yang berkebutuhan khusus tersebut, hingga pada pola pikir masyarakat yang cenderung mengabaikan kemampuan yang dimiliki oleh anak berkebutuhan khusus. Dengan adanya pandangan-pandangan tersebut, berimbas pada anak berkebutuhan khusus yang cenderung kurang mendapatkan perhatian, hidup termarginalkan, bahkan dalam suatu masyarakat tidak jarang dianggap sebagai sebuah aib.

Hal tersebut senada dengan pendapat Rachmita M. Harahap yang menyatakan bahwa salah satu dari permasalahan di Indonesia adalah kurangnya pemahaman, kesadaran dan akses terhadap hak asasi manusia yang mengakibatkan ketidakmampuan anak-anak berkebutuhan khusus dalam berpartisipasi secara utuh dalam kehidupan masyarakat (Hanum 2017).

Demikian halnya dengan Triana Rosalina Noor yang berpendapat bahwa anak berkebutuhan khusus seyogyanya dibebaskan dan diberdayakan, baik dari keterbatasan fisik maupun mentalnya (Maftuhin and Fuad 2018). Hal tersebut dapat diwujudkan dengan memberikan hak yang sama dalam bidang pendidikan secara berkesinambungan, terpadu dan penuh tanggung jawab.

Sejalan dengan tulisan Lilik Maftuhatin yang merujuk pada UndangUndang Dasar 1945 pasal 31 ayat 1 yang menyatakan bahwa setiap warga negara berhak untuk memperoleh pendidikan, dan konsep pendidikan untuk semua (education for all) yang ditegaskan dalam deklarasi universal Hak Asasi Manusia (HAM) dan slogan tersebut selayaknya mengawal kita untuk bisa terus peduli dengan isu pendidikan karena hak pendidikan adalah hak semua orang tanpa memandang kelas, ras, jenis kelamin, agama, dan bentuk muka, termasuk bagi anak berkebutuhan khusus (Maftuhatin et al. 2014).

Pendidikan Agama Islam (PAI) merupakan salah satu bagian penting bagi anak. Hal tersebut juga berlaku bagi anak berkebutuhan khusus. Sedangkan berdasarkan tujuan pendidikan nasional, pendidikan Agama merupakan hak bagi setiap peserta didik, hal ini tertuang dalam Undang-Undang No. 20 Tahun 2003 pasal 12 yang menyatakan bahwa setiap peserta didik pada setiap satuan pendidikan berhak mendapat pendidikan agama sesuai dengan agama yang dianutnya dan diajarkan oleh pendidik yang seagama. Selain itu sebagaimana tertuang dalam Peraturan Menteri Agama RI No.16 Tahun 2010 pada Bab 1 Pasal 1 ayat 1 dan 2 yang mewajibkan pendidikan agama melalui mata pelajaran di sekolah termasuk pada SLB (Muas 2016).

Dengan kata lain bahwa pendidikan agama merupakan hak asasi manusia, sebab secara jelas dinyatakan kemerdekaan dan kebebasan seseorang untuk memperoleh pendidikan agama sesuai dengan agama yang dianutnya dan diajarkan oleh guru yang seagama dengannya. Dan hal ini berlaku pada setiap satuan pendidikan termasuk sekolah khusus. Namun perlu disadari bahwa layanan pendidikan yang diberikan kepada anak berkebutuhan khusus memiliki pola yang ber $\neg$ beda dengan anak-anak pada umumnya. Oleh karena itu diperlukan pembelajaran yang padu agar anak berkebutuhan khusus mencapai target pembelajarannya yaitu kemandirian (Hanum 2017).

Dalam pembelajaran PAI untuk anak berkebutuhan khusus, mutlak manajemen pembelajaran agama Islam harus 
sedemikian rupa direncanakan, dipraktikkan dan dievaluasi, agar pembelajaran PAI memberikan pengaruh yang signifikan terhadap anak berkebutuhan khusus antara lain: berakhlak mulia, taat beribadah, percaya diri dan sebagainya.

Persoalan saat ini yang sedang dihadapi Sekolah Luar Biasa (SLB) kaitannya dengan pembelajaran PAI ada $\neg$ lah keterbatasan sumber daya manusia, dalam hal ini guru PAI yang berpen $\neg$ didikan khusus untuk profesi guru PAI Luar Biasa, minimnya buku ajar pembela $\neg$ jaran PAI bagi anak berke $\neg$ butuhan khusus pada hampir semua Sekolah Luar Biasa. Sarana dan prasarana yang belum memadai dan kemampuan pendidik agama Islam dalam menggunakan strategi yang masih kurang relevan den $\neg$ gan perlakuan yang seharusnya diterima oleh anak berkebutuhan khusus. Sehingga, sesuai dengan uraian di atas, adapun yang menjadi rumusan masalah dalam penelitian ini adalah bagaimana panorama pelak $\neg$ sanaan pembelajaran PAI bagi anak berke $\neg$ butuhan khusus di SLB ABCD Dharmawanita Herlang ?. Panorama pembelajaran yang dimaksud adalah meliputi perencanaan, pelaksanaan dan evaluasi serta kendala dalam penyelenggaraan pembelajaran PAI pada SLB ABCD Dharmawanita Herlang.

\section{LANDASAN TEORI}

\section{Pembelajaran Pendidikan Agama Islam Konsep Pembelajaran}

Menurut Aprida Pane dalam tulisannya yang berjudul belajar dan pembelajaran, menyatakan bahwa pembelajaran pada hakikatnya adalah suatu proses, yaitu proses mengatur, mengorganisasi lingkungan yang ada di sekitar peserta didik, sehingga dapat menumbuhkan dan mendorong peserta didik melakukan proses belajar. Pembelajaran dapat pula dikatakan sebagai proses memberikan bimbingan atau bantuan kepada peserta didik dalam melakukan proses belajar (Pane and Darwis Dasopang 2017).

Sedangkan menurut Haris Budiman, bahwa pembelajaran merupakan suatu kegiatan yang melibatkan seseorang dalam upaya memperoleh pengetahuan, keterampilan, dan nilai-nilai positif yang memanfaatkan berbagai sumber belajar (Budiman 2016). Atau pembelajaran dapat pula didefinisikan sebagai sebuah proses interaksi edukatif antara peserta didik, guru dan lingkungan yang melibatkan berbagai komponen pembelajaran untuk menjacapai tujuan pembelajaran yang telah direncanakan. Adapun Unang Wahidin dalam tulisannya mengenai implementasi literasi media dalam proses pembelajaran PAI dan budi pekerti menyatakan bahwa komponen sistem pembelajaran terdiri dari; tujuan pendidikan dan pembelajaran, perencanaan pembelajaran, peserta didik, guru, metode pembelajaran, media pembelajaran dan evaluasi pembelajaran (Wahidin 2018).

\section{Pendidikan Agama Islam}

Secara terminologis, Samsul Nizar menyimpulkan dari beberapa pemikiran ilmuwan bahwa pendidikan merupakan usaha sadar yang dilakukan secara bertahap dan simultan (proses), terencana yang dilakukan oleh orang yang memiliki persayaratan tertentu sebagai pendidik. Selanjutnya kata pendidikan ini dihubungkan dengan Agama Islam, dan menjadi satu kesatuan yang tidak dapat diartikan secara terpisah. PAI merupakan bagian dari pendidikan Islam dan pendidikan Nasional, yang menjadi mata pelajaran wajib di setiap lembaga pendidikan Islam (Nurlaili 2019).

Hal tersebut sejalan dengan pendapat Nurhadi yang menyatakan bahwa PAI sangat penting untuk menciptakan masyarakat yang cerdas, damai, terbuka, demokratis dan berakhlak (Nurhadi 2018). Sedangkan dalam penelitian yang dilakukan oleh Asnadar Abubakar menyatakan bahwa Pendidikan Agama Islam merupakan pendidikan yang harus 
diberikan kepada peserta didik pada semua jenjang dan jalur pendidikan sebagaimana termuat dalam Peraturan Pemerintah Republik Indonesia Nomor 55 Tahun 2007 tentang Pendidikan Agama dan Pendidikan Keagamaan pada pasal 1 ayat (1) Pendidikan agama adalah pendidikan yang memberikan pengetahuan dan membentuk sikap, kepribadian, dan keterampilan peserta didik dalam mengamalkan ajaran agamanya, yang dilaksanakan sekurangkurangnya melalui mata pelajaran/kuliah pada semua jalur, jenjang, dan jenis pendidikan (Abubakar 2016).

\section{Anak Berkebutuhan Khusus dan Sekolah Luar Biasa}

Menurut Direktorat Pendidikan Luar Biasa, anak berkebutuhan khusus adalah anak yang secara signifikan mengalami kelainan atau penyimpangan (fisik, mental intelektual, sosial dan emosional) dalam proses pertumbuhan atau perkembangannya dibandingkan dengan anak sesusianya, sehingga anak berkebutuhan khusus memerlukan pelayanan pendidikan khusus. Sekolah luar biasa (SLB) adalah tempat bagi anak berkebutuhan khusus untuk memperoleh ilmu sesuai dengan kekhususannya, dimana anak berkebutuhan khusus berhak mendapatkan pendidikan dan mengembangkan potensi yang dimilikinya (Erawati, Sudjarwo, and Sinaga 2016).

Anak berkebutuhan khusus adalah bagian dari masyarakat yang harus dibebaskan dan diberdayakan, baik dari keterbatasan fisik maupun mentalnya. Upaya tersebut dilakukan dengan cara memberikan hak yang sama dalam bidang pendidikan secara berkesinambungan, terpadu dan penuh tanggung jawab agar mereka tidak lagi dianggap sebagai warga kelas dua yang hanya dipandang sebelah mata oleh sebagian orang (Noor 2017).

Anak berkebutuhan khusus berdasarkan aspek fisik menurut Abdullah dalam (Noviandari and Huda 2018) dikategorikan ; kelainan dalam indra penglihatan (tunanetra), kelainan indra pendengaran (tunarungu), kelainan kemampuan berbicara (tunawicara) dan kelainan fungsi tubuh (tunadaksa). Sedangkan menurut PSLB masih dalam (Noviandari and Huda 2018), bahwa klasifikasi anak berkebutuhan khusus berdasarkan ketunaannya, antara lain ; tunanetra, tunarungu, tunagrahita, tunadaksa dan tunalaras. Anak yang berkebutuhan khusus yang bersekolah pada SLB, penempatannya juga disesuaikan dengan kekhususannya. SLB A dikhususkan untuk siswa tunanetra, SLB B dikhususkan untuk siswa tunarungu, SLB C dikhususkan untuk siswa tunagrahita, SLB D dikhususkan untuk siswa tunadaksa, SLB E dikhususkan untuk siswa tunalaras dan SLB G dikhususkan untuk siswa yang cacat ganda.

\section{METODE PENELITIAN}

Penelitian ini dilaksanakan di Kecamatan Herlang, Kabupaten Bulukumba, Provinsi Sulawesi Selatan. SLB ABC Dharmawanita Herlang sebagai sasaran penelitian. Penelitian ini merupakan penelitian kualitatif, dimana peneliti sebagai key instrument. Pengumpulan data dilakukan melalui observasi, wawancara dan dokumentasi. Observasi dan dokumentasi digunakan untuk melakukan pengamatan terhadap lingkungan sasaran penelitian serta wawancara mendalam dengan Kepala Sekolah dan guru Pendidikan Agama Islam SLB ABCD Dharmawanita Herlang. Pada penelitian ini, peneliti mencoba untuk memperoleh gambaran panorama pembelajaran Pendidikan Agama Islam pada anak berkebutuhan khusus di SLB ABCD Dharmawanita Herlang. Hal-hal tersebut meliputi perencanaan, pelaksanaan dan evaluasi pembelajaran Pendidikan Agama Islam serta hambatan atau kendala dalam realisasi pembelajaran Pendidikan Agama Islam pada anak berkebutuhan di SLB ABCD Dharmawanita Herlang.

Sumber data dalam penelitian ini terdiri atas data primer dan data sekunder. Sumber data primer diperoleh dari objek 
penelitian, dalam hal ini Kepala Sekolah dan guru Pendidikan Agama Islam SLB ABCD Dharmawanita Herlang. Sedangkan adapun sumber data sekunder adalah berupa dokumen pendukung, seperti dokumen kondisi sekolah (profil sekolah, visi misi, kurikum, silabus ataupun rencana pelaksanaan pembelajaran PAI dan lainlain). Data yang diperoleh dianalisis dengan tahapan reduksi data, penyajian data dan verifikasi data (Sugiyono 2012).

\section{HASIL DAN PEMBAHASAN Potret Sekolah Luar Biasa ABCD Dharmawanita Herlang}

SLB ABCD Dharmawanita Herlang didirikan pada tahun 1989, berlokasi di J1.Poros Batuasang KM.37 dari pusat Kota Kabupaten Bulukumba. Awalnya sekolah ini didirikan sebagai sekolah binaan Dharmawanita Kecamatan Herlang yang bertujuan untuk memberikan pelayanan pendidikan kepada anak berkebutuhan khusus yang ada pada beberapa Kecamatan, yaitu : Kecamatan Herlang, Kecamatan Bonto Tiro, Kecamatan Bonto Bahari dan Kecamatan Kajang. Hal tersebut sebagai upaya untuk menyediakan Pendidikan Khusus (PK) yang menangani anak berkebutuhan khusus di sekitar Kecamatan Herlang yang tidak terjangkau oleh sekolah negeri yang ada di Kabupaten Bulukumba.

Hal awal yang dikerjakan dalam melakukan perencanaan penyelenggaraan Sekolah Luar Biasa ini adalah memanggil beberapa alumni SPGLB Negeri Ujung Pandang Tahun 1988. Alumni tersebut berjumlah lima orang, menyusun program dengan mulai mendata calon peserta didik yang berkebutuhan khusus pada empat Kecamatan dan akhirnya berhasil mengumpulkan siswa dengan jumlah 27 orang dengan beberapa jenis ketunaan dan berkumpul atau tinggal di Rumah Rosbiah (langsung di Panti). Adapun biaya akomodasi, konsumsi ditanggung bersama (partisipasi para penggagas).

Lokasi pertama tempat belajar peserta didik pada bekas kantor Desa Singa tahun 1989 sampai dengan 1992, lalu berpindah pada kupos gedung KUD Maminasata tahun 1992 sampai tahun 1994, kemudian pindah ke perumahan SDN 192 Bontosuka hingga saat ini berlokasi J1.Poros Batuasang KM.37 dari pusat kota Kabupaten Bulukumba.

Sekolah ini dari tahun ke tahun mengalami perkembangan atau kemajuan, baik dari segi kualitas maupun kuantitas. Pembangunan sarana, prasana dan infastruktur dimulai pada tahun 2011 sampai pada tahun 2014 dengan bantuan bansos pihak Direktorat PK-PLK Dikdas dan Dikmen, pihak Yayasan Pendidikan Luar Biasa Bulukumba, dan dukungan dari pihak komite sekolah, serta para dewan guru dan masyarakat.

Adapun visi dari SLB ABCD Dharmawanita Herlang adalah terwujudnya lulusan yang mandiri, kompetitif dan berakhlak mulia. Visi ini dapat pula diartikan memiliki sikap dan perilaku yang tidak mudah bergantung, sikap dan tindakan yang mendorong dirinya untuk menghasilkan sesuatu, dan sikap serta perilaku yang patuh dalam melaksanakan ajaran agama. Dalam mewujudkan ketercapaian visi maka membutuhkan beberapa misi, misi tersebut yaitu menyiapkan pendidik dan tenaga kependidikan yang profesional, menyiapkan sarana dan prasarana pendidikan yang mampu mewujudkan lulusan mandiri, kompetitif dan berakhlak mulia, menyelenggarakan pendidikan yang memberikan kesempatan luas untuk mengembangkan kemampuan menolong dirinya sendiri, keterampilan, sosial akademik, bakat dan minat, menyelenggarakan layanan anak berkesulitan khusus, menyelenggarakan layanan asesmen dan konsultan inklusif dan mengembangkan keterlibatan pemangku kepentingan dalam mengelola pendidikan.

Jumlah peserta didik pada SLB ABCD Dharmawanita Herlang saat ini tercacat sebanyak 34 orang yang berasal dari Kecamatan Herlang dan beberapa Kecamatan yang berada di sekitar Kecamatan Herlang seperti Kecamatan 
Bonto Tiro, Kecamatan Bonto Bahari dan Kecamatan Kajang. Namun berdasarkan hasil wawancara dengan Kepala SLB ABCD Dharmawanita Herlang Rosbiah, S.Pd menyatakan bahwa meskipun yang tercatat sebanyak 34 orang, tetapi yang aktif mengikuti pembelajaran jauh lebih sedikit dari jumlah yang tercatat. Lebih lanjut Rosbiah menyampaikan bahwa tenaga guru juga minim, khususnya yang memiliki spesifikasi dalam bidang pendidikan luar biasa. Guru yang mengajar pada sekolah tersebut, umumnya adalah guru yang berasal dari sekolah umum.

\section{Pembelajaran PAI Anak Berkebutuhan Khusus SLB ABCD Dharmawanita Herlang}

Dalam

penyelenggaraan

pembelajaran PAI bagi anak berkebutuhan khusus di SLB ABCD Dharmawanita Herlang yang diulas pada penelitian ini, meliputi; perencanaan, pelaksanaan, metode, media, evaluasi serta kendala dalam proses penyelenggaraan pembelajaran PAI.

\section{Perencanaan Pembelajaran PAI SLB ABCD Dharmawanita Herlang}

Dalam membuat sebuah rancangan atau perencanaan pembelajaran, guru berfungsi sebagai subjek yang harus dapat menyusun berbagai program pengajaran sesuai dengan pendekatan serta motode yang akan digunakan. Selain guru harus mampu membuat perencanaan pembelajaran, kompetensi seorang guru juga dituntut untuk dimiliki, karena hal tersebut merupakan sebuah kebutuhan dalam sistem pendidikan di Indonesia. Hal tersebut sejalan dengan penegasan Hamalik dalam (Taruna 2011) bahwa Guru yang terampil mengajar tentu harus memiliki kom $\neg$ petensi baik dalam bidang pedagogisnya, profesionalnya, kepribadian dan sosial kemasyarakatannya. Tanggung jawab tersebut direalisasikan dalam bentuk melaksanakan pembinaan kurikulum, menuntun peserta didik belajar, membina pribadi, watak, dan jasmaniah siswa, menganalisis kesulitan belajar, serta menilai kemajuan belajar para peserta didik.

Menurut Hamsinah, S.Pd.I selaku guru yang mengampu mata pelajaran PAI pada SLB ABCD Dharmawanita Herlang, bahwa adapun hal-hal yang disiapkan sebelum pelaksanaan pembelajaran PAI bagi anak berkebutuhan khusus meliputi ; hal pertama yang perlu dilakukan oleh guru adalah mengidentifikasi jenis ketunaan, serta karakteristik dari peserta didik, menentuan tujuan atau capaian dari pembelajaran tersebut. Selanjutnya menyiapkan silabus dan RPP, dimana pembuatan silabus dan RPP berdasar pada kurikulum yang umumnya disadur dari sekolah umum, yaitu kurikulum 2013, yang kemudian mengalami adaptasi yang disesuaikan terhadap kondisi peserta didik pada SLB tersebut.

Setelah menyiapkan silabus dan RPP, maka selanjutnya guru menyiapkan metode serta strategi dan media yang akan digunakan dalam proses pembelajaran yang tentunya mempertimbangkan situasi peserta didik. Selain itu, guru juga merancang bentuk atau sistem evaluasi sebagai penilaian yang akan digunakan untuk mengukur kemampuan peserta didik, serta ketercapaian tujuan pembelajaran. Meskipun menurut Hamsinah, S.Pd.I bahwa penilaian secara kognitif tidak menjadi tolak ukur utama, namun lebih kepada peserta mampu menerapkan materi pembelajaran PAI dalam keseharian.

\section{Pelaksanaan Pembelajaran PAI SLB ABCD Dharmawanita Herlang}

Pelaksanaan pembelajaran memerlukan perencanaan yang matang, sehingga pelaksanaan pembelajaran dapat berjalan sesuai dengan yang diharapkan. Berikut hal-hal yang mendukung proses pelaksanaan pembelajaran PAI pada anak berkebutuhan khusus SLB ABCD Dharmawanita Herlang adalah ketersediaan ruang kelas, alat peraga, metode, strategi, sumber belajar atau guru dan alat penunjang lainnya. 


\section{Metode dan Media Pembelajaran PAI SLB ABCD Dharmawanita Herlang}

Pada proses pembelajaran, guru mengupayakan menggunakan berbagai strategi, metode dan pendekatan serta media yang dapat membantu mengoptimalkan potensi yang dimiliki oleh peserta didik. Begitu halnya pada proses pembelajaran PAI bagi anak berkebutuhan khusus pada SLB ABCD Dharmawanita Herlang. Namun dalam proses pembelajaran PAI bagi anak berkebutuhan khusus, guru seyogyanya harus mempertimbangkan beberapa hal sebelum memutuskan untuk menerapkan metode atau strategi dan media pembelajaran yang akan digunakan. Pertimbangan tersebut meliputi tujuan yang akan dicapai, kapabilitas peserta didik maupun guru bersangkutan, karakteristik dan jenis ketunaan dari peserta didik, situasi serta kesiapan peserta didik menerima materi pelajaran. Meskipun pertimbanganpertimbangan tersebut seharusnya telah diputuskan oleh guru pada tahap perencanaan pembelajaran.

Berdasarkan hasil wawancara dengan Hamsinah, S.Pd.I sebagai guru yang mengampu mata pelajaran Pendidikan Agama Islam pada SLB ABCD Dharmawanita Herlang, menyatakan bahwa terdapat beberapa metode yang biasanya digunakan dalam proses pembelajaran PAI untuk anak berkebutuhan khusus. Metodemetode yang dimaksud diantaranya adalah metode ceramah, demonstrasi, pembiasaan atau pengulangan, tanya jawab dan pemberian tugas. Metode-metode tersebut biasanya dikombinasi dan disesuaikan dengan situasi dan kesiapan peserta didik menerima materi pelajaran. Selain itu, menurut Hamsinah, S.Pd.I bahwa pertimbangan penentuan metode yang digunakan juga berdasar pada jenis ketunaan peserta didik.

Proses pelaksanaan pembelajaran PAI umumnya menurut Hamsinah, S.Pd.I bagi anak berkebutuhan khusus dominan bersifat teacher learning centre, dimana guru masih menjadi pusat atau sumber belajar. Dalam proses pembelajaran peserta didik didampingi dan dibimbing oleh guru secara satu persatu atau sering disebut sebagai pemebelajaran bersifat individual teaching, karena perlakuan yang diberikan berbeda untuk setiap peserta didik berdasarkan jenis ketunaannya. Misalnya guru PAI bersangkungan mengajar lima orang peserta didik dalam satu kelas yang memiliki empat jenis ketunaan yang berbeda, maka guru PAI bersangkutan dalam proses pembelajaran akan mendampingi dan memberikan perlakukan serta menerapkan strategi dan metode berbeda kepada setiap peserta didik berdasarkan jenis ketunaannya.

Pada peserta didik dengan jenis ketunaan tunanetra, metode pembelajaran yang biasanya digunakan adalah metode ceramah. Metode ceramah adalah metode penyampaian materi pelajaran dengan memberikan penjelasan dan deskripsi secara sepihak oleh guru terhadap peserta didik, dengan tujuan agar peserta didik mampu memahami materi pelajaran tersebut. Misalnya materi mengenai gerakan sholat dan tata cara berwudu, maka guru bersangkutan akan menjelasakan dan mendeskripsikan mengenai gerakan salat tersebut. Kemudian untuk membantu proses pembelajaran, guru bersangkutan menggunakan media pembelajaran seperti audio yang dapat membantunya dalam menyampaikan bacaan salat dan wudu serta dapat dimainkan secara berulang-ulang. Guru PAI bersangkutan menambahkan bahwa biasanya media pembelajaran yang digunakan bagi anak yang berkebutuhan khusus seperti tunanetra adalah menggunakan buku braille, namun karena belum tersedianya buku-buku PAI dalam braille, sehingga guru hanya menggunakan media yang tersedia.

Adapun metode pembelajaran yang dominan digunakan pada peserta didik tunarungu adalah metode demonstrasi. Metode demonstrasi menurut Sumantri adalah sebagai salah satu cara menyajian pembelajaran dengan memperagakan dan mempertunjukkan kepada peserta didik 
suatu proses, suatu benda tertentu yang sedang dipelajari baik dalam bentuk yang sebenarnya maupun dalam bentuk tiruan yang dipertunjukkan oleh guru atau sumber belajar yang memahami topik bahasan yang didemonstrasikan (Rini, Tangkas, and Said 2014). Menurut guru PAI bersangkutan, bahwa dalam proses pembelajaran PAI bagi peserta didik tunarungu misalnya pada materi taharah dalam hal ini berwudu, guru menampilkan poster yang berisi tata cara pelaksanaan berwudu, kemudian mendemonstrasikan disertai dengan gerakan bibir. Selain itu mengenai bacaan ketika berwudu, guru menggunakan media pembelajaran berupa audio visual, karena guru PAI bersangkutan juga masih memiliki keterbatasan dalam menjelaskan kepada peserta didik menggunakan abjad jari atau isyarat jari maupun bahasa tubuh.

Metode pembelajaran yang dominan diterapkan bagi peserta didik tunagrahita dan tunadaksa, menurut Hamsinah, S.Pd.I adalah metode demonstrasi dan metode pengulangan. Meskipun disamping itu, guru PAI bersangkutan juga tidak menutup kemungkinan untuk melakukan kombinasi metode dalam proses pembelajaran. Misalnya dikombinasikan dengan cooperative learning, dimana peserta didik diberikan kesempatan untuk dibentuk dalam kelompok-kelompok kecil untuk membantu sama lain-lain, namun hal tersebut tentunya harus disesuaikan dengan keadaan dan kesiapan peserta didik dalam menerima materi pelajaran. Kemudian media yang digunakan dalam proses pelaksanaan pembelajaran bagi peserta didik tunagrahita dan tunadaksa adalah audio visual.

\section{Evaluasi Pembelajaran PAI SLB ABCD Dharmawanita Herlang}

Evaluasi merupakan bagian akhir dan termasuk komponen penting dalam sebuah siklus pembelajaran, termasuk yang dilakukan guru yang mengampu pembelajaran PAI pada SLB ABCD Dharmawanita Herlang. Evaluasi menjadi sebuah komponen penting dalam proses pembelajaran, karena pada tahap ini guru dapat mengetahui keefektifan dan ketercapaian tujuan pembelajaran. Serta selain itu juga dapat menjadi feed back atau evaluasi bagi guru PAI dalam menyempurnakan kegiatan program pembelajaran, baik itu dari segi perencanaan, metode, strategi, dan pendekatan-pendekatan yang digunakan selama proses pembelajaran.

Berdasarkan hasil wawancara dengan Hamsinah, S.Pd.I, bahwa evaluasi pembelajaran PAI yang dilakukan pada SLB ABCD Dharmawanita Herlang menggunakan bentuk evaluasi yang berbeda bagi setiap peserta didik. Evaluasi tersebut dibedakan berdasarkan ketunaan yang dimiliki peserta didik, serta mempertimbangkan tingkat kemampuan yang dimiliki peserta didik. Sehingga dalam melaksanakan evaluasi pembelajaran PAI, guru bersangkutan harus menyiapkan beberapa varian soal sesuai tingkatan kemampuan peserta didik, metode dan strategi evaluasi yang disesuaikan dengan jenis ketunaannya. Dalam hal ini berdasarkan hasil wawancara dengan guru PAI sebagai berikut :

“....dalam pembuatan soal tetap berpedoman pada materi yang ada pada RPP dengan menyesuaikan kemampuan setiap peserta didik. Soal dibuat dengan sangat sederhana agar mudah dipahami oleh peserta didik, sebagai implikasinya saya harus menyiapkan beberapa jenis-jenis soal yang berbeda untuk setiap peserta didik".

Dalam proses pelaksanakaan evaluasi pembelajaran PAI yang dilakukan oleh Hamsinah,S.Pd.I tetap merujuk pada tiga komponen yaitu kognitif, afektif dan psikomotorik. Tesnya pun meliputi tes tertulis dan tidak tertulis (praktik). Tes tertulis dapat diterapkan pada peserta didik dengan kebutuhan khusus tunarungu dan tunagrahita, sedangkan pada peserta didik dengan kebutuhan khusus tunanetra dan tunadaksa yaitu dengan metode tanya jawab. Pelaksanaan evaluasinya pun tidak dilaksanakan secara bersamaan, melainkan 
dilakukan secara terpisah untuk setiap peserta didik berdasarkan ketunaannya.

Misalnya bagi peserta didik tunarungu, dalam mengerjakan soal evaluasi, maka guru yang bersangkutan biasanya menuliskan soal pada papan tulis atau menyiapkan lembaran soal yang telah dicetak. Sedangkan untuk peserta didik dengan jenis ketunaan tunagrahita, yaitu dengan menyiapkan lembaran soal yang telah dicetak, kemudian membacakan soal dan didampingi dalam pengerjaan soal tersebut. Lain halnya dengan peserta didik tunarungu dan tunadaksa, dalam pelaksanaan evaluasi pembelajaran PAI, guru bersangkutan biasanya menggunakan metode tanya jawab. Sehingga dalam pelaksanaan evaluasi pembelajaran PAI memerlukan waktu yang cukup lama, bahkan menurut Hamsinah, S.Pd.I bahwa bahkan terkadang jawaban yang diberikan tidak sesuai dengan pertanyaan yang diberikan. Namun, dalam evaluasi tersebut menurut guru PAI bersangkutan menyatakan bahwa kemampuan kognitif tidak menjadi acuan utama, bahwa lebih kepada peserta didik mampu menerapkan dalam kehidupan sehari-hari. Maka dari itu, selain melakukan evaluasi pada ranah kognitif peserta didik, guru PAI bersangkutan juga melakukan pengamatan dan praktik secara langsung.

\section{Kendala dalam Penyelenggaraan Pembelajaran PAI SLB ABCD Dharmawanita Herlang}

Berdasarkan hasil wawancara dengan Rosbiah, S.Pd selaku Kepala Sekolah dan Kepala Yayasan, menyatakan bahwa kendala yang hadapi saat ini adalah pertama kekurangan guru yang memiliki spesifikasi khusus dalam pendidikan luar biasa, tidak terkecuali guru yang mengajarkan mata pelajaran PAI. Menurut Rosbiah, S.Pd bahwa karena adanya keterbatasan tersebut, sehingga umumnya tenaga pengajar pada SLB ABCD Dharmawanita Herlang disadur dari sekolah umum. Tenaga pengajar di SLB tersebut pun umumnya adalah guru yang mengajar pada sekolah umum. Kedua, kurikulum PAI yang digunakan juga umumnya merupakan kurikulum yang berasal dari sekolah umum yang sedikit mengalami modifikasi dan adaptasi untuk anak berkebutuhan khusus. Ketiga, masih minimnya ketersediaan buku-buku agama bagi peserta didik berkebutuhan khusus yang disediakan oleh pihak SLB. Khususnya bagi peserta didik tuna netra, yaitu peserta didik yang memiliki keterbatasan pada indra penglihatan, yang mana dalam hal ini membutuhkan buku breille.

Sedangkan dari pihak guru, dalam hal ini guru PAI Ibu Hamsinah, S.Pd.I menyatakan bahwa sebagai guru yang mengajarkan mata pelajaran PAI untuk anak yang berkebutuhan khusus, memiliki tantangan tersendiri selama proses pembelajaran, terlebih karena spesifikasi pendidikan yang dimiliki tidak berada pada ranah tersebut. Selain itu, guru harus mampu mengenal dan mengidentifikasi siswa berdasarkan ketunaannya, agar dapat mempermudah guru dalam melakukan pengajaran. Tantangan lainnya yang perlu dipersiapkan sebelum mengajar adalah mempersiapkan bahan ajar untuk peserta didik yang dibedakan berdasarkan ketunaannya. Misalnya Hamsinah, S.Pd.I yang mengajar peserta didik dengan tiga jenis ketunaan dalam kelasnya sekaligus, yaitu tunanetra, tunarungu dan tunagrahita, maka Hamsinah, S.Pd.I akan mempersiapkan bahan ajar yang topik yang sama, namun menggunakan metode pengajaran yang berbeda.

Selain itu, menurut Hamsinah, S.Pd.I bahwa pendekatan secara emosional terhadap peserta didik juga sangat dibutuhkan oleh guru, sebab peserta didik yang berkebutuhan khusus memiliki kecenderungan akan lebih nyaman dan lebih mudah berkompromi terhadap instruksi yang disampaikan oleh guru apabila telah memiliki kedekatan emosial. Pendekatan secara emosional terhadap peserta didik yang berkebutuhan khusus ini tentunya membutuhkan waktu dan 
pembiasaan, khusunya bagi peserta didik tunagrahita.

\section{PENUTUP}

Berikut hasil penelitian yang telah dilakukan mengenai panorama pembelajaran PAI pada anak berkebutuhan khusus pada SLB ABCD Dharmawanita Herlang, yang meliputi perencanaan, pelaksanaan dan evaluasi pembelajaran PAI; Kurikulum PAI yang digunakan mengikuti kurikulum pada sekolah umum, yaitu kurikulum 2013.

Metode yang dominan digunakan pada proses pembelajaran PAI adalah metode yang bersifat teacher learning centre, seperti metode ceramah dan metode demontrasi. Pembelajaran bersifat individual teaching. Sistem evaluasi tetap menggunakan tiga ranah ; kognitif, afektif dan psikomotorik, meskipun komponen kognitif tidak menjadi standar utama, namun lebih kepada peserta didik mengimplementasikan materi pembelajaran PAI dalam keseharian.

Adapun kendala dalam penyelenggaraan pembelajaran PAI pada SLB ABCD Dharmawanita Herlang adalah pertama kurangnya guru PAI yang memiliki spesifikasi khusus dalam pendidikan luar biasa, kedua belum tersedianya kurikulum PAI yang dirancang khusus untuk anak berkebutuhan khusus, karena selama ini kurikulum PAI yang digunakan juga umumnya berasal dari sekolah umum yang sedikit mengalami modifikasi dan adaptasi untuk anak berkebutuhan khusus. Ketiga, minimnya ketersediaan buku-buku PAI bagi peserta didik berkebutuhan khusus yang disediakan oleh pihak SLB, khususnya bagi peserta didik tunanetra yang membutuhkan buku braille. Keempat dalam proses pembelajaran PAI dengan peserta didik yang berkebutuhan khusus, guru perlu melakukan pendekatan secara emosional sebab peserta didik yang berkebutuhan khusus memiliki kecenderungan akan lebih nyaman dan lebih mudah berkompromi terhadap instruksi yang disampaikan oleh guru apabila telah memiliki kedekatan emosial.

\section{UCAPAN TERIMA KASIH}

Kehadiran tulisan ini tidak terlepas dari bantuan berbagai pihak. Melalui kesempatan ini, menulis menyampaikan terima kasih kepada pihak SLB ABCD Dharmawanita Herlang, terkhusus kepada Ibu Rosbiah, S.Pd selaku Kepala Sekolah dan pihak yayasan yang telah menyambut peneliti dengan tangan terbuka untuk melakukan penelitian. Kepada Ibu Hamsinah, S.Pd.I. selaku guru yang mengampu mata pelajaran PAI pada SLB ABCD Dharmawanita Herlang atas waktu yang telah diluangkan kepada peneliti. Serta ucapan terima kasih kepada segenap redaksi jurnal Educandum Balai Litbang Agama Makassar yang telah bersedia untuk menerbitkan tulisan ini.

\section{DAFTAR PUSTAKA}

Abubakar, Asnandar. 2016. "Pelaksanaan Pendidikan Agama Pada Sekolah Negeri PAREPARE." Al-Qalam 19 (2): https://doi.org/10.31969/alq.v19i2.15 7.

Budiman, Haris. 2016. "Penggunaan Media Visual Dalam Proses Pembelajaran." Jurnal Pendidikan Islam 7.

Erawati, Ika, Sudjarwo Sudjarwo, and Risma Sinaga. 2016. "Pendidikan Karakter Bangsa Pada Anak Berkebutuhan Khusus Dalam Pendidikan Inklusif." Jurnal Studi Sosial 4 (1).

Hanum, Lathifah. 2017. "Pembelajaran PAI Bagi Anak Berkebutuhan Khusus." Jurnal Pendidikan Agama Islam 11 (2):

217-36. https://doi.org/10.14421/jpai.2014.11 2-05.

Maftuhatin, Lilik, Kata Kunci, Evaluasi Pembelajaran, Anak Berkebutuhan Khusus, and Kelas Inklusif. 2014. "Evaluasi Pembelajaran Anak 
Berkebutuhan Khusus (Abk) Di Kelas Inklusif Di Sd Plus Darul 'Ulum Jombang." Jurnal Studi Islam Oktober 5 (2): 1978-306.

Maftuhin, M, and A Jauhar Fuad. 2018. "Pembelajaran Pendidikan Agama Islam Pada Anak Berkebutuhan Khusus." Journal An-Nafs: Kajian Penelitian Psikologi 3 (1). https://doi.org/10.33367/psi.v3i1.502

Muas, Rosdiana. 2016. "Pelaksanaan Pendidikan Agama Islam Di SMPLB Negeri Balikpapan." Al-Qalam 19 (2): 209. https://doi.org/10.31969/alq.v19i2.16 4.

Noor, Triana Rosalina. 2017. “Analisis Desain Fasilitas Umum Bagi Penyandang Disabilitas (Sebuah Analisis Psikologi Lingkungan)." Journal An-Nafs: Kajian Penelitian Psikologi 2 (2): 187-211. https://doi.org/10.33367/psi.v2i2.438

Noviandari, H, and T.F Huda. 2018. "Peran Sekolah Dalam Pendidikan Anak Berkebutuhan Khusus Di SDLB PGRI Bangorejo Banyuwangi." Jurnal Psikologi 5 (1): 29-37.

Nurhadi. 2018. "Manajemen Penilaian Pembelajaran Menggunakan Kurikulum 2013." Al-Hayat: Journal of Islamic Education 2 (1): 63-78. http://alhayat.or.id/index.php/alhayat /article/view/20.

Nurlaili. 2019. "Pendidikan Agama Islam Dalam Pandangan Multikultural (Analisis Model Dan Pengembangannya)." International Seminar on Islamic Studies, IAIN Bengkulu, March 282019 | Page263. 263-269., 263-69. http://repository.iainbengkulu.ac.id/2 961/.

Pane, Aprida, and Muhammad Darwis Dasopang. 2017. "BELAJAR DAN PEMBELAJARAN."

FITRAH:Jurnal Kajian Ilmu-Ilmu $\begin{array}{lll}\text { Keislaman } 3 & 3 & \text { (2): } 333 .\end{array}$ https://doi.org/10.24952/fitrah.v3i2.9 45.

Rini, I. M. Tangkas, and Irwan Said. 2014. "Meningkatkan Hasil Belajar Siswa Melalui Penggunaan Metode Demonstrasi Pada Mata Pelajaran IPA Di Kelas III SDN Inpres Tunggaling." Jurnal Kreatif Tadulako Online 2 (1): 67-81. https://media.neliti.com/media/public ations/116575-ID-meningkatkanhasil-belajar-siswa-melalui.pdf.

Sugiyono. 2012. "Metode Penelitian Kuantitatif, Kualitatif Dan R \& D.Bandung:Alfabeta." Metode Penelitian Kuantitatif, Kualitatif Dan $\mathrm{R} \&$ D.Bandung:Alfabeta. https://doi.org/10.1017/CBO9781107 415324.004.

Taruna, Mulyani Mudis. 2011. "Kompetensi Guru Pendidikan Agama Islam.” Analisa 18 (2): 180. https://doi.org/10.18784/analisa.v18i 2.132 .

Wahidin, Unang. 2018. "Implemtasi Literasi Media Dalam Proses Pembelajaran Pendidikan Agama Islam Dan Budi Pekerti." Edukasi Islami : Jurnal Pendidikan Islam 7 (2): 229. https://doi.org/10.30868/ei.v7i2.284. 